\title{
関係情報の記述による船体構造の設計法に関する 基礎的研究
}

\author{
正員 野 本 敏 治* 正員 濱 田 邦 裕** \\ 正員 青 山 和 浩*
}

Basic Studies on Design of Ship Structure by Describing Relation Information

by Toshiharu Nomoto, Member Kunihiro Hamada, Member

Kazuhiro Aoyama, Member

\begin{abstract}
Summary
In order to implement a product model which can be applied to shipbuilding industry, the authors have developed the integrated system called SODAS (System of Design and Assembling for Shipbuilding). In the design stage, SODAS is able to generate product information such as "Room" and "Part". In the system, it is mainly considered how the product information is generated.

In this paper, the system is revised up to a level of conceptional use. Particulary, deep consideration is paid for relation of product information which is not proposed in SODAS. In order to realize this, some new concepts are introduced. What and how relation informations should be described in the system is mainly discussed.

Some examples are shown. One is an application to design modification which is not applied to the existing SODAS. Another is the use of design procedure information for a new ship, by using design procedure information which were already done in past.
\end{abstract}

\section{1. 緒言}

\section{1 はじめに}

現在のところ, 日本の製造業は国際的に高い競争力を保 持し，日本を世界で一流の経済国家とする基盤を成してい る。その優秀な生産能力を支えているのは, 製造業に従事 する一人一人の労働者の能力であるといっても過言ではな い。しかしながら国際環境の変化や日本国内の労働環境の 変化によって, 現在, 労働者の能力に強く依存する従来の 日本の産業形態は破綻をきたし始めている。このような状 況のもと, 次世代の設計・生産システムとして CIM (Computer Integrated Manufacturing)が着目されている。

CIM を構築するためには, 設計・生産活動などで必要と される様々な情報を計算機上において統合化することが重

* 東京大学工学部船舶海洋工学科

** 東京大学大学院工学系研究科

原稿受理 平成 7 年 1 月 10 日 春季講演会において講演 平成 7 年 5 月 17,18 日
要である。情報の統合化を行うための一つの概念として, 製品モデルの概念が提唱されている。製品モデルとは, 設 計・生産活動において必要となる製品情報を可能な限り計 算機内部に記述し，製品が有する情報を統合的に管理する ためのモデルである。設計・生産活動において必要となる 製品情報は膨大な量であるため, これらの情報を効率よく 計算機上に記述していくことは重要である。また, 設計・ 生産活動において生成・利用される情報を統合的に管理す る環境においては，ある情報を生成する際に，その情報と 密接に関連する情報が既に生成され管理されていることが 重要である。従って, 製品モデルを構築する上では, 様々 な情報の間の関係を明確にし，その情報同士の関係を利用 することによって, 記述された情報を有効に利用し必要十 分な情報を獲得することが重要である。

一般的に製品情報を獲得する活動として設計活動を捉え ることができる1”。設計者は製品情報を獲得するために意 思決定を行い, 製品に関する様々な情報を生成する。この 様々な情報を製品モデルに記述するためには, 製品モデル における表現手法を検討する必要がある。例えば, 4 つの区 画によって構成される Cargo Hold の情報を管理する場合 
には, 個々の区画が取り出せることの他に Cargo Hold 全 体が取り出せることなどが要求される。しかし, 計算機上 に個々の区画が独立した情報として記述されている場合に は, 個々の区画を取り出すことは容易であるが, 4 つの区画 を含む Cargo Hold 部全体を取り出すことは困難である。 このことを可能にする方法の一つとして, Cargo Hold 部 全体を取り出すために個々の区画の間の関係に着目し, そ の関係を利用して 4 つの区画を取り出すことが考えられ る。つまり計算機内に 100 の製品情報が独立した情報とし て記述された場合には，100の情報しか取り出すことがで きない。しかしながら情報の間の関係を記述することによ って，100の情報から 100 以上の情報を取り出すことが可 能となる。以上より, 設計者の様々な認識に対応すること のできる製品情報を計算機上に記述するためには，区画や 部材が独立した情報として存在するだけでは不十分であ り, 区画や部材の間の関係が必要であることが理解できる。

また, 船の設計において生成される新たな板や骨は, 既 に存在する製品情報と関係していることが多い。例えば, ある区画に対して仕切り板を入れる場合には区画に制約を 受けるように仕切り板が設計される。従って, 仕切り板を 定義する際に, 設計者の頭の中において仕切り板が区画に 従属するという関係が生成されていると考えることができ る。このような区画や部材の間の関係は, 関係情報を利用 して表現可能である。従って, 関係情報を用いて製品情報 の生成を支援することができると考えられる。

以上のように関係情報は, 製品情報の生成や利用の立場 から考えると重要な役割を果たしており, 製品モデルを構 築するために必要な情報と捉えることができる。

\section{2 本研究の目的}

著者らは造船 CIM 構築に向けて製品モデルに関する研 究を行っており, 既研究において, 区画を定義する部屋, 部材を定義する部材情報, 部材間の接合部を定義する接合 関係情報などが製品モデルの情報として有効であることを 報告している23)4)。

本研究では製品情報の間の関係情報に着目し，著者らの 研究開発しているSODAS (後述) 上に関係情報を記述し利 用することを検討する。即ち, 製品情報の生成や利用に関 与する関係情報を製品定義システム内に記述し, 造船の区 画設計・構造設計を支援するシステムを構築することを目 指す。

具体的に, 本研究の目的を以下に示す。

（1）関係情報を中心に据えて区画設計・構造設計をモ デル化し, 計算機に記述すべき関係情報を明確にする。

（2）上記の関係情報を計算機に記述・利用することを 検討する。尚, この部分はSODAS をべースとして構築し, 製品情報としては既研究において報告している部屋, 部材, 接合関係情報を対象とする ${ }^{2) 3}$ 。

\section{2. 既存システムの概要}

本研究は著者らの既存システムをベースに, 計算機に関 係情報を記述し利用することを目的として行われている。 そこで本章では, 著者らが研究開発している船を対象にし た設計・生産支援システムである, SODAS (System Of Design and Assembling for Shipbuilding)の概要につい て述べるとともに, SODASの持つ情報の再整理を行う。

\subsection{SODAS の製品情報}

SODAS は造船のための製品モデルを構築することを目 的としたプロトタイプ・システムである。SODASでは, 以 下の製品情報が製品モデルの情報として定義されている。

（1）部材情報

船体構造の基本単位である板部材・骨部材に関する情報 が記述されるモデルであり, 製品モデルを構成する基本要 素であると考えることができる。現在は部材情報として平 面部材・直線部材のみを対象としている。

（2）接合関係情報

部材間の接合関係を表現するモデルであり，生産計画に おいては溶接に関する情報としても有効に利用される。

(3) 部屋

船倉および区画などの空間形状を表現するモデルであ り, 容積が計算可能なソリッドモデルによってその形状が 定義されている。また, 部屋は部材情報や後述するユニッ トの情報を管理している。

(4) ユニット

船体の部分構造を構成する “構造単位”を表現するモデ ルであり,トランスリング・ボトムトランス・サイドトラ ンス・ロンジなどの部材の集合体として定義される。ユニ ットには構造を構成する部材情報が記述される。

\subsection{SODAS における設計支援}

2.1 節において述べた製品情報は以下に示す設計機能に よって生成される。

\section{（1）空間設計機能}

区画設計において生成される区画や船倉の間の仕切り板 は, 既に存在する区画や船倉の制約を受けて形状が決定さ れる。この制約を利用して仕切りとなる板部材を定義し, この仕切り板によって元の親部屋を新しい子部屋に幾何学 的に分割することができる。

この機能を著者らは空間設計機能と呼んでいる3。以上 の部屋の分割機能の使用によって生成される親部屋と子部 屋との関係は, 親部屋に子部屋が従属するといった関係に あり, 部屋の情報を階層構造で管理することによってこの 関係を表現している。

\section{（2）内構部材設計機能}

構造設計では部屋の壁を支えるための内構部材を設計す る必要がある。生成すべき内構部材はトランスリングのよ うな主要な構造部材のほか, 横強度部材や緃強度部材が考 
慮される必要がある。これらの内構部材は部屋を構成する 板部材によって制約を受けるため,この制約を利用すれば 生成される内構部材の形状をある程度確定することが可能 である。内構部材の生成に関してはパラメトリックな設計 を可能としている2) 。

（3）設計変更への対応

子部屋が親部屋に従属するという関係や内部構造が部屋 に従属するという関係は階層構造として記述されている。 更に, 部屋の分割情報及び内部構造のパラメー夕を寸法情 報として記述している。従って, ある部屋の寸法情報が書 き換えられた場合には, 記述されている寸法情報と階層構 造を利用して, 部屋の再分割を行うことができる5。このこ とは, 部屋や部材の間の関係を利用することによって, 設 計変更を可能にしていると考えることができる。

\subsection{SODASにおける関係情報}

以上述べてきたように, SODAS の設計支援システムで は子部屋が親部屋に従属する関係や, 内構部材が部屋を構 成する板に制約されるなどの関係が重要な役割を果してい る。これらの関係は, 部屋の間の関係を階層構造を用いて 表現していることからも理解できるように, 製品情報の間 の縦の関係として捉えられる。

しかしながら，このような繸の関係のみでは，様々な問
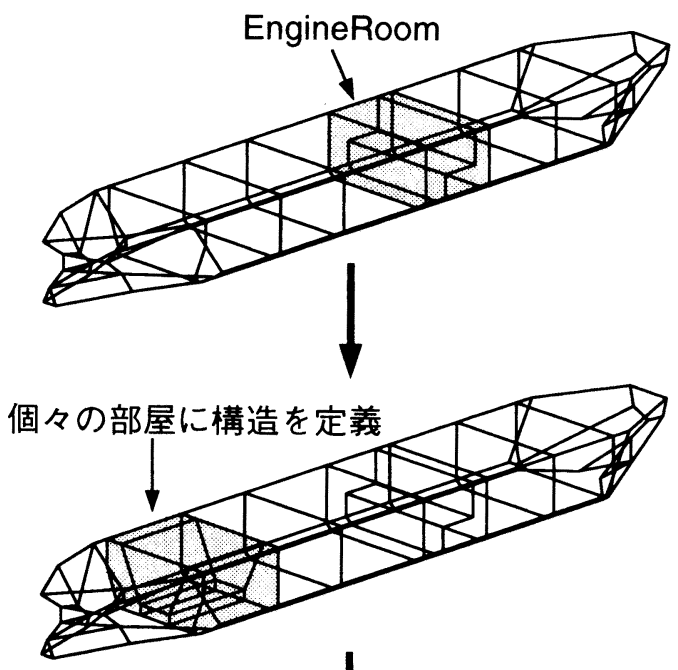
上記を5回繰り返す

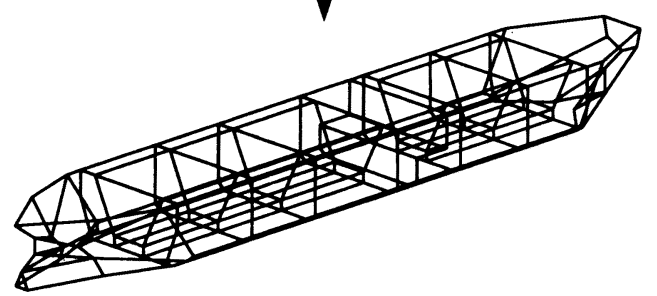

Fig. 1 Example of Design Flow in Existing SODAS
題が発生する。例えば異なる複数の部屋に対して同じ構造 を定義したい場合には, 対象となる部屋の間に関係が必要 である。このような関係は現状の縦の関係のみでは十分に 記述されているとは言いがたい。Fig. 1 は中央部に Engine Roomを持ち, Engine Roomの前に 3 つ, 後に $2 つ$ つ Hold を持つオアキャリアーである。この船に対して, 設計 者が前後の Hold 部に共通の構造を定義したい場合におい ても, 現状のシステムでは 5 つの各々の部屋に構造を定義 することが必要となる。また，このようにして生成された 構造において二重底部を認識することを考えてみる。二重 底部を構成する $5 つ$ 部屋は異なった階層の中にあり (Fig. 2), 縦の関係のみでは二重底部を取り出すことは不 可能である。以上のような問題を解決するためには, 縦の 関係に加えて横の関係が必要であろう。

従って, 現在のSODAS に記述されている製品情報の間 の縦の関係（階層構造）のみでは製品情報の間の関係を十 分に表現することができず，これに加えて横の関係（ネッ トワーク）が必要であることが理解ができる。

\section{3. 区画設計・内構部材の設計のモデル化}

前章において，製品を表現するためには製品情報と関係 情報とが必要であることを述べた。

- 製品情報：

部屋，板部材などの製品を構成する物を表現する情報 - 関係情報 :

製品情報の間の綐の関係（階層構造）

製品情報の間の横の関係（ネットワーク）

従って, 製品定義システムとしては上記の情報を効率良 く生成することが望まれる。

ところで上記の情報は製品を表現する情報であるため, 設計の結果として生成される情報である。一方, 設計は設 計要求を基に製品に関する情報を獲得する過程であるの で，設計過程において製品を定義するための情報が生成さ れている。従って, 設計過程に存在する製品情報や関係情 報を定義するための情報を明確にし，その情報を基に製品 情報や関係情報を獲得することができれば，設計の結果で

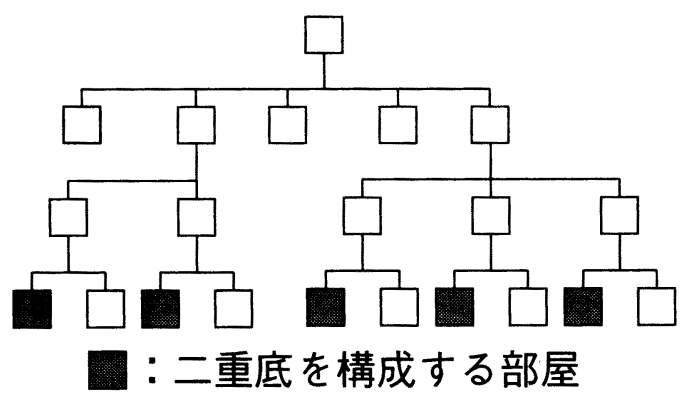

Fig. 2 Hierarchy of Rooms 
ある製品情報や関係情報を効率良く生成することが可能で ある。

本章では, 区画の設計や内構部材の設計のモデル化を行 い, 設計過程に存在する製品情報や関係情報を生成するた めの情報を明確にする。尚, 設計過程に存在する製品情報 や関係情報を生成するために必要な情報を, 本研究では設 計情報と呼ぶことにする。

・設計情報：設計過程に存在する製品情報や関係情報を 生成するために必要な情報

更に, 設計要求の明確化から設計情報の生成までを設計 者の行う設計過程, 生成された設計情報を基に製品情報と 関係情報を獲得する過程を計算機によって支援する設計過 程と考え, 設計情報を基に製品情報や関係情報を効率良く 生成するための手法を検討する。

\section{1 区画設計のモデル化}

\section{1 .1 区画設計の特徴}

船の主要目・区画配置を決定し, 船の諸性能を満足する ことが区画設計の目的である。そのために，設計者は船の 諸性能を満足するように仕切り板を設計し，様々な区画を 决定する。ここで，バルクキャリアーやタンカーなどの船 によって要求される項目が異なるため, 生成される区画や 板の情報は異なったものになる。しかしながら，ある区画 を仕切り，新たな板や区画などの製品情報を生成するとい う視点では共通である。また, 関係情報は物と物とを関連 付ける情報であるため, 新たな区画や板などの製品情報が 生成される時に他の区画との間の関係が生成されると捉え られる。そこで本研究では，区画設計を「仕切るという設 計情報を生成し，その情報を基に区画や板などの製品情報 と関係情報を生成する」という行為が繰り返して行われる 設計過程であるとモデル化する。また，区画は板に囲まれ た空間であるため, 新たな区画の生成は板の生成によって 間接的に行われると考えられる。

以上を整理すると，区画設計においては，製品情報や関 係情報は「ある区画を板で仕切り，新たな区画を生成する」 という設計情報によって生成されると考えることができ る。

従ってシステムとしては, 上記の設計情報が記述された 場合には，区画や板などの製品情報と，製品情報の間に関 係情報を生成することが求められる。

・生成される製品情報：「板」・「区画」

・設計情報：「仕切る」

\section{1 .2 区画設計の流れ}

設計情報を明確にするために,設計の流れについて考え， 流れの中にどのような情報が含まれているかを整理するこ とは重要である。ところで, 3.1 .1 において，「仕切る」と いう設計情報を基に, 設計情報から製品情報や関係情報を 獲得する過程であると区画設計をモデル化した。しかし「仕 切る」という設計情報にどのような情報が含まれているか
は明確になっていない。このため, 具体的に「4つの区画で 構成される Hold を Inner Bottom Plate で仕切り，4つの Cargo Hold と Double Bottom を生成する」という設計例 について考え，設計情報「仕切る」を明確にする。(Fig. 3)

（1）設計要求を満足するために「Hold を，Cargo Hold と Double Bottom とに仕切る」必要があると考 え,「Cargo Hold と Double Bottom とに仕切る= Inner Bottom Plate を設計する」という情報を利用す ることにする。

（2）具体的な仕切り方を考える。

（3）各々の Hold の形状や寸法情報を基に4つの Inner Bottom Plateの形状が決定され, 更に各々の Hold と設計されたInner Bottom Plate を基に 4 つ の Cargo Hold と Double Bottom の形状について計 算し決定する。

（4）各々 4 つの Inner Bottom Plate, Cargo Hold,

Double Bottom の情報が獲得される。

上記において述べた区画設計の流れについて，製品情報 と関係情報の生成という見地より，流れの中に含まれる情 報の整理を試みると以下に示す様になる。

（1）の段階において, 設計要求を基に各々の Hold に Cargo Hold, Double Bottom, Inner Bottom Plate が 設計されることが設計者によって決定される。ここで， Cargo Hold, Double Bottom, Inner Bottom Plate は 製品情報として定義されるものであり，この時点で

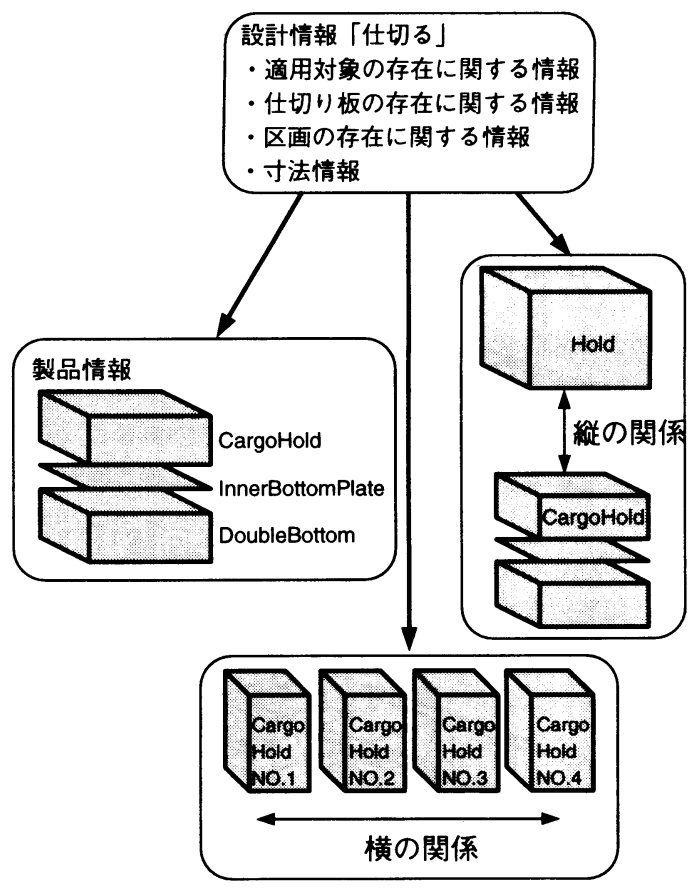

Fig. 3 Flow of Room Design 
各々の Cargo Hold, Double Bottom, Inner Bottom Plate の存在が決定されることになる。従って, 製品情 報として定義される区画や板の存在を決定するための 設計情報が設計者によって生成されていると考えるこ とができ, 本研究ではこの情報を「存在を决定する設 計情報」と呼ぶ。「存在を決定する設計情報」には, 製 品情報として定義される「区画や板の存在に関する情 報」とその情報の「適用対象の存在に関する情報」を 記述する必要がある。

(2)の段階は, Cargo Hold, Double Bottom, Inner Bottom Plate の形状を決定するための情報が生成さ れる。これらは,（1）において存在が决定された製品 情報の形状を決定するための情報である。本研究にお いては, この情報を「状態を決定する設計情報」と呼 ぶ。

（３）の段階は, 設計情報を基に製品情報を獲得する部 分である。本研究では製品情報や関係情報を計算機内 に記述することとともに,この 2 つの情報の獲得を計 算機によって支援することを考える。そこで本部分を 設計機能として計算機内に構築することを加えて考え る。

（4）の段階で, 製品情報が定義される。ここで, 適用 対象の区画と新たに生成された区画との関係に着目し た場合, 生成された区画は適用対象の区画に制約を受 ける。従って, 製品情報の間の縦の関係が生成される。 更に生成された 4 つの Double Bottom の間の関係に 着目した場合, 同じ設計情報によって生成されたとい う関係が生成される。従って, 製品情報の間の横の関 係が生成される。また, 適用対象である製品情報が複 数ある場合において, それらの情報が異なる階層にあ ることが考えられる。従って, 横の関係は階層を越え て生成されることも考慮する必要がある。

以上より「仕切る」という設計情報は以下に示す様に整 理できる。

設計情報：仕切る

・存在を決定する情報

(a ) 適用対象の存在に関する情報

（b 1) 生成する仕切り板の存在に関する情報

(b 2)生成する区画の存在に関する情報

・状態を決定する情報

(c) 形状の獲得に関係する寸法や制約条件

上記の設計情報を製品モデルの上に写像することによっ て, 新たな製品情報と関係情報を獲得することが可能であ る。

生成される製品情報

・ (b 1) と (c)によって生成される仕切り板

・(b 2) と（c)によって生成される区画

生成される関係情報
- 適用対象の区画と生成された製品情報との間の縦 の関係

・生成された区画の間や生成された板の間の横の関 係

\section{2 内構部材の設計のモデル化}

区画設計において用いた手法と同様の方法で, 内構部材 の設計のモデル化を行う。

\subsection{1 内構部材の設計の特徵}

船全体の構造強度や部分的な構造強度を満足するための 構造様式の検討が構造設計の目的である。設計者は, 構造 強度を満足するため補強部材である板や骨を設計する。こ こで, 船全体の縦曲げ強度を満足するために Bottom Plate にロンジをつけるという設計を考えてみる。この設 計では「船全体の縦曲げ強度を満足する」という目的のも とに，設計者は「Bottom Plate にロンジをつける」と意思 決定を行う。このことは, 設計要求である「船全体の縦曲 げ強度を満足する」を満たすために, 設計者によって「Bottom Plate にロンジをつける」という設計情報が生成され たと考えることができる。更に「Bottom Plate にロンジを つける」という設計情報によって, 適用対象である Bottom Plate に添うように設計されるロンジの存在が決定され, その後に寸法情報などのロンジの形状定義に関与する情報 が決定され製品情報が獲得されることとなる。

この設計に含まれる設計情報について整理すると，

1） Bottom Plate とロンジとの間の縦の関係を生成す るための情報

2）生成されたロンジの間の横の関係を生成するための 情報

3）ロンジの製品情報を獲得するための情報 が必要であることが理解できる。

本研究では, これらの情報によって構成される設計情報 を「補強する」と定義する。また, 構造設計を「補強する という設計情報を生成し，その情報を基に補強部材の製品 情報と関係情報とを生成する」という行為が繰り返して行 われる設計過程であるとモデル化する。また区画設計と同 様に, 生成された設計情報を基に製品情報や関係情報を獲 得する過程を計算機によって支援することを考える。

構造設計における設計情報と製品情報を以下に示す。

・生成される製品情報：「板」・「骨」

・設計情報：「補強する」

3.2.2 内構部材の設計の流れ

設計情報「補強する」に含まれる情報を明確にするため, 3.2.1において述べた「Bottom Plateをロンジで補強す る」という設計の流れについて考えてみる。(Fig. 4)

（1）設計要求を満たすために，設計者によって 「BottomPlate をロンジで補強する」という設計情報 が生成される。

（2）ロンジの形状を決定するために必要な寸法を決定 


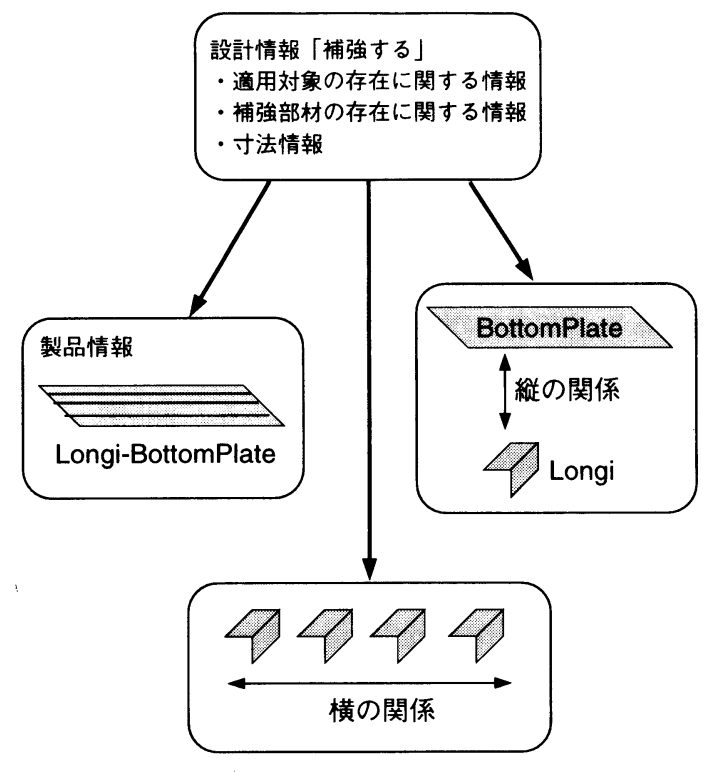

Fig. 4 Flow of Structural Design

する。

( 3 ) Bottom Plate の形状とロンジの寸法をベースに ロンジの形状を決定する。

（4）ロンジの製品情報と関係情報とが獲得される。

上記において述べた内構部材の設計の流れについて, 製 品情報と関係情報の生成という見地より, 流れの中に含ま れる情報の整理を試みると以下に示す様になる。

（1）の段階において, 設計要求を基に補強部材の「存 在を決定する設計情報」が生成される。「存在を決定す る設計情報」には, 製品として定義される「補強部材 の存在に関する情報」とその情報の「適用対象となる 基の板の存在に関する情報」が含まれる。但し, 補強 部材にはロンジのように板に添うように生成される部 材の他に, トランスリングのように区画を占めるよう に生成される部材がある。従って, 適用対象としては 板と区画の両方を考慮する必要がある。

(2)の段階は，ロンジの断面形状や取付位置を決定す るための情報, 即ち「状態を決定する設計情報」が生 成される。

（3）の段階は，設計情報を基に製品情報を獲得する部 分である。区画設計と同様に製品情報や関係情報の 獲得を計算機によって支援するために，本部分を設 計機能として計算機内に構築することを加えて考え る。

（4）の段階で，ロンジの製品情報が定義される。また， この際に BottomPlate とロンジとの間の縦の関係が 生成される。更に, 生成されたロ、ジが複数ある場合 には,生成されたロンジの間に横の関係が生成される。
以上より内構部材の設計における設計情報「補強する」, 製品情報, 関係情報は以下の様に整理できる。

設計情報：補強する

・存在を決定する情報

(a ) 適用対象の存在に関する情報

(b) 生成する補強部材の存在に関する情報

・状態を決定する情報

(c) 形状の獲得に関係する寸法や制約条件 生成される製品情報

・ (b)と（c）によって生成される補強部材

生成される関係情報

・適用対象と生成された補強部材との間の縦の関係

・生成された補強部材の間の横の関係

\section{3 製品情報と関係情報の獲得のために}

3.1 節及び 3.2 節において区画設計・内構部材の設計に おける設計情報, 製品情報, 関係情報について整理してき た。

上記の情報の中で, 設計情報の一部である「状態を決定 する設計情報」は, 形状の獲得に関係する寸法や制約条件 を表現するものであるので, 既研究において構築されてい る寸法情報5)を利用することができる。また, 区画や板など の製品情報も，2 章で述べた様にそれらの情報を表現する モデルが存在する。従って,「関係情報のモデル化」と「存 在を決定する設計情報のモデル化」が重要である。

\section{4. 情報の記述のモデル化}

\section{1 情報の表現のために}

3 章において「関係情報のモデル化」と「存在を決定する 設計情報のモデル化」が重要であると述べた。本節では, 「関係情報」の表現手法に要求される項目, 及び「存在を決 定する設計情報」の表現手法に要求される項目について整 理し,その上でこれらの情報の表現手法について検討する。

\section{1 .1 関係情報の表現のために}

既に述べたように, 関係情報としては製品情報の間の縦 の関係と横の関係を計算機に記述することが必要である。 ところで船は十万点以上の部品によって構成されるため, これら全ての製品情報の間の関係をそのまま記述した場合 には,その情報量は莫大なものに達することは容易に想像 できる。できるだけ少ない情報を基に, 多くの情報を取り 出すという視点から考えた場合には, 製品情報に何らかの 属性を記述し，その属性を利用することによって自由に製 品情報の間の関係を取り出すことが望まれる。更にその属 性が製品情報としても有効であることが望ましい。

\section{1 .2 存在を決定する設計情報の表現のために}

存在を决定する設計情報のモデル化を行う上で注意すべ き点は,この情報が概念的な情報で構成されているという ことである。そして, 概念的には同じ情報であっても, 寸 法情報を獲得して「板」や「区画」として製品情報を獲得 
した場合には，異なる情報になることである。例えば， Cargo Holdに対して何かを設計するという設計情報が存 在する場合には, Cargo Hold の形状はいうまでもなく Cargo Holdの数が幾つあろうとも, 全ての Cargo Hold に対してこの設計情報を適用する必要がある。このことに 対応するためには，幾何情報に左右されない情報によって 設計情報を表現し，かつ，その情報を基に製品情報や関係 情報を自由に取り出せることが要求される。このためには， 関係情報を表現するための属性と同じ表現手法であること が望ましいと考えることができる。

\section{1 .3 情報の表現手法に要求される項目}

4.1.2 において, 関係情報と存在を決定する設計情報と は属性情報を用いた同一の手法によって表現すべきである

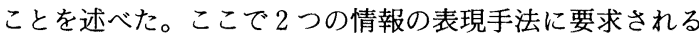
項目を合わせて整理すると以下に示す様になる。

（1）製品情報の間の縦の関係を表現できること。

（2）製品情報の間の横の関係を表現できること。

（3）概念的な「仕切る」「補強する」という設計情報を 表現可能であること。

ここで，上記の項目を満たす情報の表現方法を見いだす ために，実際の設計者が区画や板をどのようにして取り出 しているかについて考えてみる。例えば, Cargo Hold-NO. 1 という区画を表現する際に「8つの頂点を持った空間で 各々の頂点の座標值は…」などという幾何情報を用いる設 計者はいない。当然のことながら「Cargo Hold-NO.1」と いう名前（造船用語）を用いて表現する。以上より，設計 者は区画や板を名前の概念（造船用語）を用いて表現して いると理解できる。

\section{2 名前による情報の表現}

本節では, 4.1 節において述べた関係情報と設計情報の 表現方法に要求される 3 つの項目に対して名前という情報 が合致するかを考えてみる(Fig. 5)。

\section{（1）製品情報の間の縦の関係の表現}

Inner Bottom Plate-Hold-NO. 1 という名前の例につ いて考えてみる。この名前が Hold-NO. 1 の二重底板を意 味していることは言うまでもない。しかしながら, Inner Bottom Plate-Hold NO. 1 の後半 (Hold-NO. 1) が設計情 報の適用対象を示し, 名前全体で生成された製品情報を示 すと考えた場合には，この名前は製品情報の間の縦の関係 を表現することが可能である。

\section{（2）製品情報の間の横の関係の表現}

Cargo Hold-Port Side-NO. 1 という名前の例について 考えてみる。この名前を区画にそのまま記述するのであれ ば，単一の区画しか取り出すことができない。しかしなが ら, 名前の情報を Cargo Hold, Port Side, NO. 1 という 3 つの情報に分けて区画に記述し，その中のどの情報を用い た時も記述した区画を取り出せるようにしたとする。この ようにシステムを構築すれば, Cargo Hold と指定すると
(1)縦の関係の表現のために

設計される製品情報の名前

InnerBottomPlate-Hold-NO.1

設計情報の適用対象

(2)横の関係のために

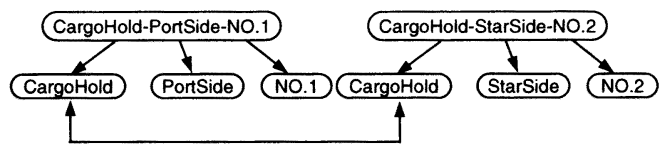

(3)存在を決定する設計情報の表現のために

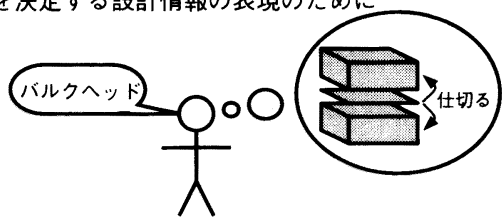

Fig. 5 Description by using Attribute of its Name

きには Cargo Hold という情報を持つ全ての区画を取り出 すことが可能である。従って，名前の情報を利用して区画 や板の間でネットワークを構成し（区画や板の階層が異な っていても可), 複数の区画や板を自由に取り出すことが可 能である。

（3）概念的な設計情報の表現

名前は具体的な数値等の情報を含んでいない非常に概念 的な情報である。また「A=区画を仕切るもの」とあれば， 造船に関係する人間であれば「 $\mathrm{A}=$ バルクヘッド etc.」と考 えるであろう。このように考える場合，バルクヘッドとい う造船用語は, 識別のための名前であると同時に, 造船に 関係する人間にとっては，「仕切る」という設計情報を表現 するものであると考えることができる。

以上のように，名前は単なる識別記号ではなく様々な情 報を含んだ非常に有効な情報である。そこで，本研究では 情報の表現方法として名前の概念を用いることにした。そ して,この名前の概念を利用することによって, 4.3 節以降 に示すモデル化が可能となる。

4.3 名前の概念による設計情報「仕切る」のモデル化

ある区画を板で「仕切る」という設計について考えてみ る。例えば, Cargo Hold に仕切り板を入れ, Cargo Hold NO. 1 と NO. 2 とを生成するということは, 幾何学的に は面と 2 つ立体の生成であるが，名前という属性で考え た場合には Cargo Hold-NO.1 と NO. 2 及び両者を仕切 る板の生成である。従って，板で「仕切る」ことによって， 元の区画の情報の他に, 新たに生成される区画には, NO. 1 あるいは NO. 2 という属性が獲得されることになる。

以上より「仕切る」の中の存在を決定する設計情報は「あ る区画に対して仕切り板の存在を决定し，仕切り板によっ て新たな属性を持った区画の存在を決定する情報である」 
と整理できる。そして新たに生成される区画には，元の区 画の名前と，仕切られることによって獲得される名前が記 述されることになる。

以上を踏まえて，名前の概念を利用して「仕切る」とい う設計情報のモデル化を行い, 製品情報や関係情報との対 応を示したのが Fig. 6 と Fig. 7 である。

まず，設計情報の適用対象を表すモデルであるが，この モデルには設計情報の適用される区画の名前の情報を記述 するとともに，製品情報である区画との間に対応関係を発 生する機能が必要である。

次に，板の存在を決定するモデルについては，生成する 板の名前と区画の存在を決定するモデルを記述する必要が ある。そして, 板の存在を決定し, 存在を決定した板に名 前をつける必要がある。

最後に，区画の存在を决定するモデルには，生成される 区画に与える名前の情報を記述する必要がある。更に，区 画の存在を決定し，存在を決定した区画に対して名前をつ ける必要がある。

以上のようにモデルを構築すれば，設計情報が記述され る場合には，製品情報である区画や板には自動的に名前の 情報が獲得されることになる。いいかえれば，新たに生成 された区画や板にも名前の情報によって緃の関係や横の関 係が獲得されることになり，同じように設計情報を適用す

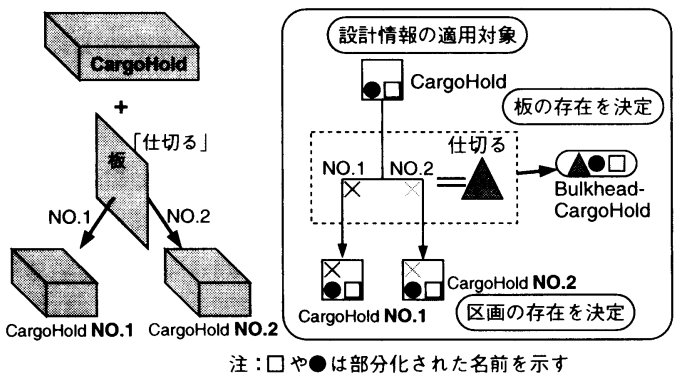

Fig. 6 Modeling of Design Information (1)

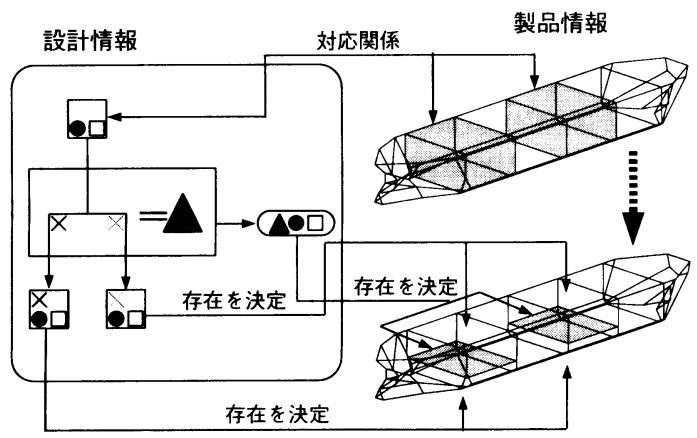

Fig. 7 Relation between Design Information and Entity ( 1)
ることが可能ということである。従って, 最初の板や区画 のみに名前を定義すれば, 後から生成される区画には設計 情報を基に自動的に名前が生成されることになる。

4.4 名前の概念による設計情報「補強する」のモデル化 「仕切る」と同様に属性レベルで考えた場合，「補強する」 の中の存在を决定する設計情報は「設計情報の適用対象で ある板や区画に対して，新たな属性を持った補強部材の存 在を决定する情報である」と整理できる。以上より，名前 の概念を利用して「補強する」という設計情報のモデル化 を行い, 製品情報との関係を示したのが Fig. 8 と Fig. 9 で ある。

まず，設計情報の適用対象を表すモデルであるが，この モデルには設計情報の適用される区画や板の名前の情報を 記述するとともに，区画や板との間に対応関係を発生する 機能が必要である。

更に, 補強部材の存在を決定するモデルについては，生 成する補強部材の名前を記述する必要がある。そして，補 強部材の存在を決定し，存在を決定した補強部材に名前を つける必要がある。

以上のモデルの構築によって, 設計情報が記述される場 合には，区画と同様に補強部材には設計情報を基に自動的 に名前の情報が獲得され，新たに生成された補強部材にも 縦の関係と横の関係を持たせることが可能である。

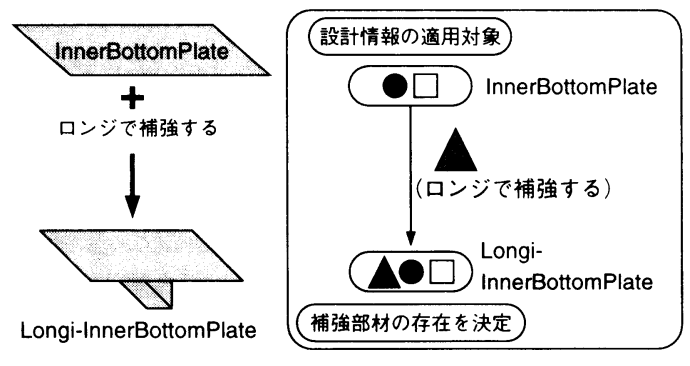

注 :ロやは部分化された名前を示す

Fig. 8 Modeling of Design Information (2)

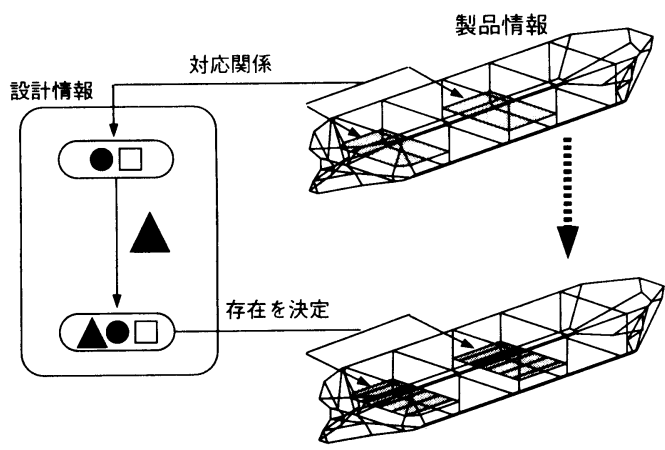

Fig. 9 Relation between Design Information and Entity ( 2) 
また, 本章は存在を決定する設計情報と製品情報や関係 情報を中心に述べてきたが，これらの区画や板の形状を決 定するには, 既存の寸法情報を存在を決定する設計情報に 付随する形で記述し, 名前の概念を用いて存在を決定され た区画や板に対して，その形状を決定する際に利用すれば 良いということになる。

以上より, 本研究の目的である設計支援システムの構築 のためには, Fig. 6-9 のモデルを基に, 各々の情報を表現で きるようにシステムを構築することが重要である。

\section{5. 設計情報と関係情報のシステム化}

本章においては，4章のモデルをシステム上でどのよう に表現するかについて述べる。尚, 本システムは, 既存シ ステムと同様にオブジェクト指向言語である Object Works Smalltalk (Release 4.1)を開発言語として使用 し, Work Station (Sun SPARC Station 10)上において 構築されている。

\section{1 設計情報のシステム化}

設計情報のシステム化のために定義したオブジェクトを Fig. 10 に示す。

以後, 各々のオブジェクトについて述べる。

5.1 .1 設計情報「仕切る」のシステム化

（1）設計情報の適用対象: Target Room Object 設計情報の適用対象を表現するオブジェクトとして

\section{設計情報「仕切る」Ｄivide Information Object}

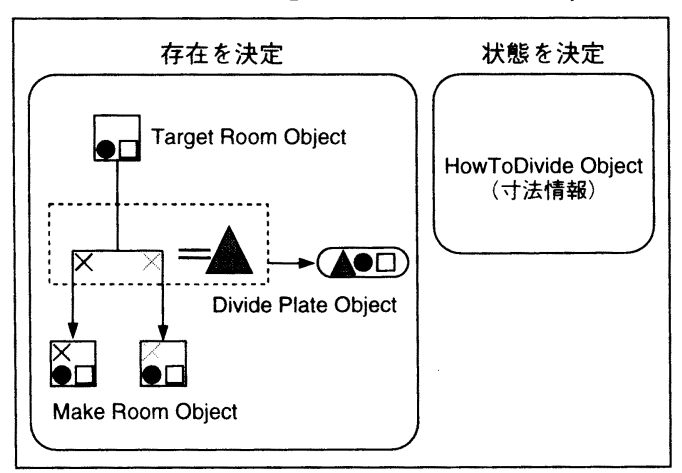

設計情報「補強する」Reinforce Information Object

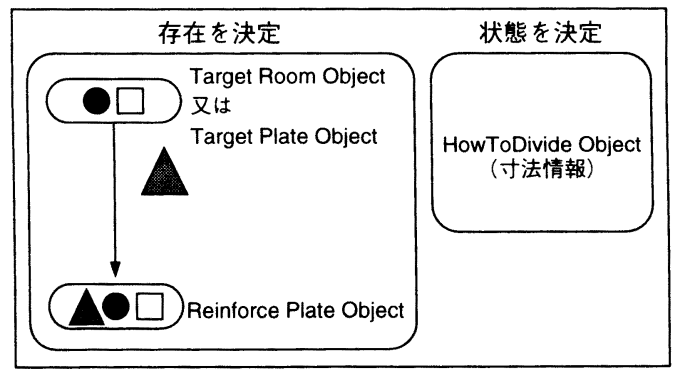

Fig. 10 Objects in Design Information
Target Room Object を定義した。このオブジェクトには, 名前の情報が記述される。そして, 区画の名前との間に対 応関係を発生させることによって, 設計情報の適用される 全ての区画を見つけだすことが可能である。尚，このオブ ジェクトは区画設計における設計情報「仕切る」を表現す る Divide Information Objectに記述され管理されてい る。

（2）板の存在の決定 : Divide Plate Object

板の存在を決定するオブジェクトとして Divide Plate Object を定義した。このオブジェクトには, 板の名前と, 区画の存在を決定する Make Room Object が記述されて いる。そして, 設計機能を介して製品情報である板の存在 を決定し名前をつけることが可能である。尚, このオブジ エクトも Divide Information Objectに記述され管理され ている。

（3）区画の存在の決定: Make Room Object

区画の存在を決定するオブジェクトとして Make Room Object を定義した。このオブジェクトには, 名前の情報が 記述され，設計機能を介して製品情報である区画の存在を 決定し名前をつけることが可能である。このオブジェクト は既に述べたように Divide Plate Objectに記述され管理 されている。

（4） 寸法情報：HowTo Divide Object

このオブジェクトは既研究によって構築されているもの である。但し,このオブジェクトの記述先が部屋から Divide Information Object に変更されている。この変更に よって寸法情報を単一の区画のみで利用するのではなく, 設計情報の適用された全ての区画において利用することを 可能にしている。

（5）設計情報「仕切る」: Divide Information Object 設計情報を表現するオブジェクトとして Divide Information Object を定義した。このオブジェクトには, 結果 的に上記 4 つのオブジェクトが記述され, 更に Target Room Object, Divide Plate Object, Make Room Object が関係付けられている。このオブジェクトを設計機能を介 して利用することによって新たな製品情報が獲得され, 獲 得された製品情報には名前が付けられる。

また, 複数の Divide Information Object が存在する場 合には互いの持つ適用対象と区画の存在を決定する情報の 間の関係を利用して, 設計手順を生成することが可能であ る。

尚, このオブジェクトは複数の部屋や板を同時に扱うこ とが必要なため, 船の設計情報として記述され管理されて いる。

5.1 .2 設計情報「補強する」のシステム化

（1）設計情報の適用対象：Target Room Object 又は Target Plate Object

構造設計における設計情報の適用対象は, 区画のみでな 
く板も表現する必要がある。このため5.1.1において述べ た Target Room Object に加えて Target Plate Object を 定義した。Target Plate Objectにも名前の情報が記述さ れ，製品情報である板や骨の持つ名前との間に対応関係を 発生させる。

尚, これらのオブジェクトは設計情報「補強する」を表 現する Reinforce Information Objectに記述され管理さ れている。

（2）補強部材の存在の決定 : Reinforce Plate Object 補強部材の存在を決定するオブジェクトとして Reinforce Plate Object を定義した。このオブジェクトには, 補強部材の名前が記述されている。そして, 設計機能を介 して製品情報である補強部材の存在を決定し名前をつける ことが可能である。尚,このオブジェクトも Reinforce Information Object に記述され管理されている。

（3） 寸法情報：How To Divide Object

このオブジェクトは既研究によって構築されているもの である。但し「仕切る」の場合と同様に, このオブジェク トの記述先がユニットから Reinforce Information Object に変更されている。

（4）設計情報「補強する」: Reinforce Information Object

設計情報を表現するオブジェクトとして Reinforce Information Object を定義した。このオブジェクトには, 結果的に上記 3 つのオブジェクトが記述されている。また, このオブジェクトも, 船の設計情報として記述され管理さ れている。

\section{2 関係情報のシステム化}

本システムを構築するにあたり, 関係情報として新たに 定義する必要があるのは部材と区画の名前の情報（板や区 画の間の縦の関係と横の関係）である。このように製品情 報の間の関係を, 名前の概念を用いて製品情報に属性情報 として記述することによって, 既存システムへの影響を狭 い範囲に抑えることができる。以下，各々の情報を表現す るオブジェクトについて記す。尚, 本システム中の部材や 区画の名前は, 池田の著書(6) を参考に構築した。

(1) 区画の名前: Room Name Object

区画の名前を表現するこのオブジェクトには前章におい て述べた名前の情報 (Cargo Hold-Port Side-NO.1の場合

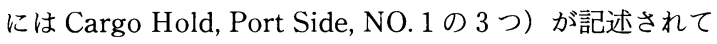
おり, 名前の情報の 1 つ 1 つは「仕切られる」ことによっ て生成される。そして各々の区画は Room Name Object を利用することによって縦の関係や横の関係を生成するこ とができ, 設計者の認識に近い形で区画を取り出すことが 可能である。このオブジェクトが区画を表現する部屋に記 述されていることは言うまでもないことである。

(2) 部材の名前: Plate Name Object

部材の名前を表現するこのオブジェクトにも区画と同様
に, 名前の情報が記述されており, 名前の情報の 1 つ 1 つ は「仕切られる」あるいは「補強される」ことによって生 成される。そして区画と同じように部材についても, Plate Name Objectによって縦の関係や横の関係を生成し, 設計 者の認識に近い形で部材を取り出すことが可能である。こ のオブジェクトは部材の情報として記述されている。

\section{3 設計機能について}

設計機能とは計算機に記述された設計情報を基に製品情 報を獲得する機能である。

既存のSODASにおける設計機能は単一の区画と寸法 情報が与えられた場合に，仕切りとなる板部材を定義し， 生成された板部材によって元の親部屋を新しい子部屋に幾 何学的に分割し, 親部屋と子部屋の間に階層構造を構成す るというものであった。

それに対して本システムでは関係情報を利用することに よって設計機能の支援範囲を広げている。具体的には, 複 数の設計情報が存在する場合にはその各々の関係によって 設計手順を生成する。更に名前による関係を利用して設計 情報が製品上で自分が働くべき場所を探しだす。そして設 計情報を基に区画や板などの製品情報を定義し, 出来上が った製品情報は新たに名前を獲得し基の区画や板と同様に 自由な取り出しが可能になるというものである。

\section{6. 本システムから見た設計過程}

本研究では関係情報に着目し, 区画設計・構造設計のモ デル化とシステムの構築を行った。これによって, 設計に 含まれる様々な情報の一部である設計情報と製品情報と関 係情報の 3 つの情報が, 整理されてシステム上に記述され ている。このようなシステムの見地から設計過程を見直す ことも, 複雑な設計過程を明確にしていく上で意義のある ことと考えられる。本章では, 本研究によって構築された システムの見地から, 設計過程を再整理する。

\section{1 ミクロな設計とマクロな設計}

本システムの特徵は, 関係情報に着目し, この関係情報 を名前の概念を利用して計算機上に記述した点にある。そ して, 製品情報や関係情報を効率良く生成するために，区 画設計を「仕切る」という設計情報を繰り返し生成する過 程, 構造設計を「補強する」という設計情報を繰り返し生 成する過程とモデル化した。更にそれらの設計情報を基に 製品情報と関係情報を獲得する情報変換機能を計算機上に 設計機能として構築した。

本システムにおける設計のモデルでは, 設計情報が繰り 返し生成されることによって, 製品情報はステップ・バイ・ ステップで獲得されていくこととなる。また, 設計は設計 要求を基に製品情報を獲得する行為とされている。以上よ り, 設計要求の製品情報への変換は少しずつ行われると捉 えたことになる。そして, 製品全体の情報は少しずつ獲得 された製品情報が集まって決定されることになる。 


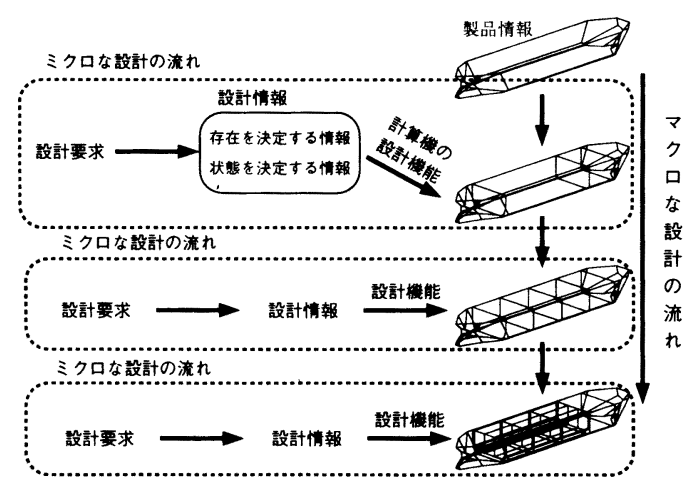

Fig. 11 Model of Design Flow in This System

ここで, 一部分について製品情報や関係情報を獲得する 設計を「ミクロな設計」と呼び, 製品全体の情報を決定す る設計を「マクロな設計」と呼ぶことにする。この場合, 「マクロな設計」は「ミクロな設計」が多数集まって構成さ れることになる。更に,「マクロな設計の流れ」は「ミクロ な設計」の集合（順序も重要）として捉えることが可能で ある。(Fig. 11)

以上より，本研究では設計の流れを 2 つ側面から捉え てシステムを構築したと考えることができる。

・ミクロな設計：製品の一部分について情報を獲得する こと。本研究においては設計要求から 1 つの設計情報 が生成され更に製品の一部の製品情報や関係情報が獲 得されるまでの流れを示す。また, 関係情報に着目す る場合には，1つの緹の関係が生成されるまでの過程 と考えることができる。

・マクロな設計：ミクロな設計の集合として定義される 製品全体の情報を獲得する設計。繸の関係の複合体と して捉えることもできる。

\section{2 設計情報と設計機能}

既に述べたように「ミクロな設計」は製品の一部分につ いて設計要求から設計情報を生成し, 生成された設計情報 を基に設計機能によって製品情報や関係情報を獲得する過 程である。ここで, 設計情報と設計機能について再整理す ると以下の様になる。

・設計情報：設計要求を基に設計者によって決定される 製品情報や関係情報の獲得に関与する情報

・設計機能：設計情報を基に製品情報と関係情報とを獲 得することであり, 計算機に求められる部分である

本研究においては, 設計情報を名前の概念を利用して計 算機に記述すると共に, 製品情報にも名前の概念を利用し て縦の関係と横の関係を表現した。これによって計算機の 設計機能による支援範囲が広がったといえる。以上より， 設計機能と設計情報は表裏一体の関係にあると考えること ができる。
また，本研究では設計情報を 2 種類の情報によって整理 した。即ち, 存在を決定する情報と, もう 1 つは状態を決 定する情報である。存在を決定する情報はあまりに当たり 前であり, 設計者は殆ど意識せずに使用している。しかし ながらこの 2 つ情報について考えてみると, 存在を決定 する情報が主であり，それに付随する形で状態を決定する 情報が存在することになる。

\section{3 マクロな設計の流れ}

前節までにおいて「ミクロな設計」について整理できた ので，本節ではそれを踏まえた上で，マクロな設計につい て考えてみる。

ここで，設計情報として「板 A をロンジで補強する」と 「区画 $\mathrm{B}$ を板 $\mathrm{A}$ で仕切る」という 2 つの設計情報があった とする。「板 A をロンジで補強する」という設計情報を製品 に対して適用するためには, 板 $\mathrm{A}$ が存在することが前提と なる。従って「板 A をロンジで補強する」という設計情報 を製品に対して適用するのは「区画 B を板 A で仕切る」と いう設計情報よりも必ず後でなければならない。

このように, マクロな設計の流れは設計情報から非常に 大きな影響を受ける。また, 個々の設計情報が正確に記述 されている時には, マクロな設計の流れは作り出すことが できるものである。

\section{7. 本システムによる船の設計}

本システムでは, 船体構造の設計は「仕切る」補強する」 という設計情報を繰り返し生成することによって行われ る。従って, どのようなタイプの船であっても, その構造 が「仕切る」あるいは「補強する」ことによって生成され るのであれば，本システムは利用可能である。以下，本シ ステムを利用した設計の流れについて示す。

\section{1 本システムにおける区画設計}

本システムに拈ける区画設計は, 以下に述べる「ミクロ な設計の流れ」の繰り返しによって進行していく(Fig. 12)。

\section{（1）設計情報の適用対象の決定}

名前を入力することによって, 設計情報の適用対象を決 定する (即ち, Target Room Object を生成する)。名前の 入力の方法によっては, 単一の区画のみでなく複数の区画 を対象とすることも可能である。ところで, 船全体を表現 する区画には 'Hull'という名前が与えられて生成される。 従って, 船全体を設計情報の適用対象としたい場合には 'Hull' という名前を入力すればよい。また Target Room Object の生成と同時に設計情報である Divide Information Object が生成される。

（2）板及び区画の存在を決定する設計情報の入力

空間設計機能を使用する Editor 上で，板 A は区画 B と 区画 C を仕切るものであると記述し, 板の存在を决定する Divide Plate Objectと区画の存在を決定する Make 


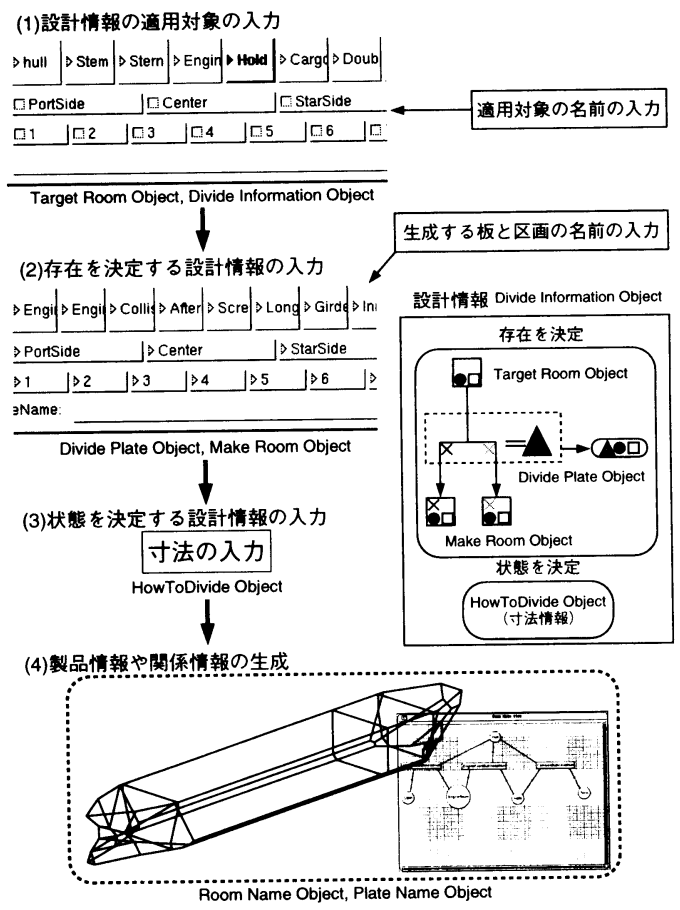

Fig. 12 Design Flow of Room Design in This System

Room Object を生成する。この時に設計者が入力するの は, 先に述べた名前の情報である。尚, Make Room Object は Divide Plate Objectの情報として管理され, Divide Plate Object は Divide Information Object の情報として 管理される。

\section{（３）状態を決定する設計情報の入力}

状態を決定する設計情報である寸法の入力を行う。この 寸法情報を扱うのが How To Divide Object である。寸法 情報の生成については, 既存の SODAS をそのまま利用し ている。但し, 生成された寸法情報は, 今までのように部 屋が管理するのではなく, 設計情報である Divide Information Object の情報として管理されることになる。

\section{（4）製品情報や関係情報の生成}

設計情報を基に空間設計機能を使用し，設計情報の適用 対象となる全ての区画に，新たな区画と仕切り板を生成す る。ここで, 新たな区画や仕切り板は, 幾何情報のみでな く設計情報によって名前の情報(Room Name Object 又は Plate Name Object)を獲得する。

本システムによって生成される区画や板は名前の情報を 利用して縦の関係や横の関係を生成することが可能であ る。また，関係情報の立場から区画設計について考えてみ ると，区画設計は様々な製品情報の間の関係の生成である とも考えることができる。

\section{2 本システムにおける内構部材の設計}

従来の SODAS における内構部材の設計は単一の部屋
(1)設計情報の適用対象の入力
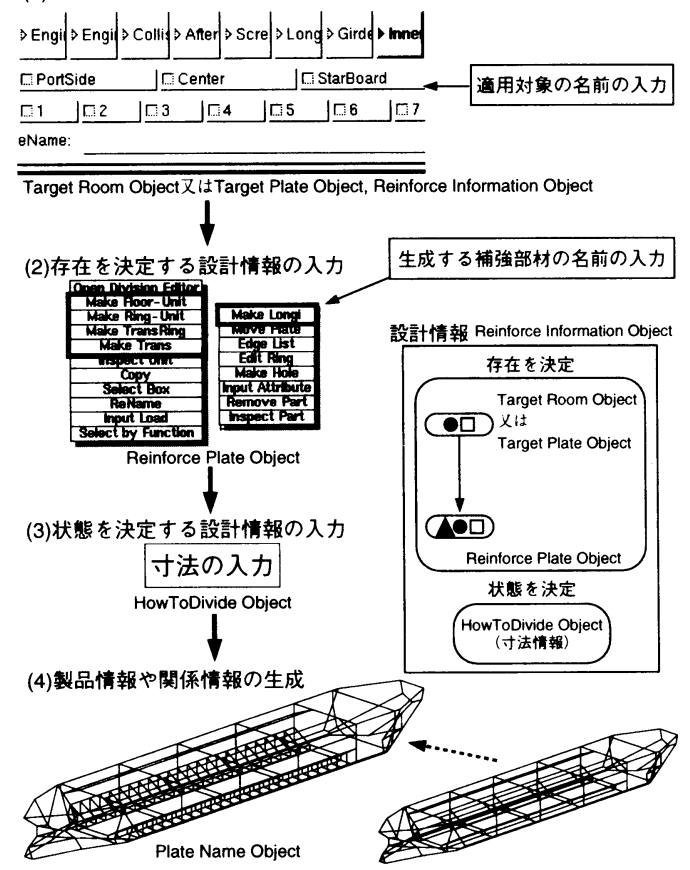

Fig. 13 Design Flow of Structural Design in This System

や板を選択し，その部分にパラメトリックに部材を設計す るというものであった。本システムにおいては生成された 板や区画の関係情報を利用して, 複数の板や部屋に対して 同時に内構部材を設計することを可能にした。

尚, 対象とした内構部材はユニットの概念を利用して設 計できるトランスリング, トランス, ロンジ，フロアプレ ートの 4 種類である。以下にその流れを示す (Fig. 13)。

（1）設計情報の適用対象の決定

名前を入力することによって, 設計情報の適用対象を決 定する (即ち, Target Room Object 又は Taget Plate Object を生成する)。区画設計と同様, 名前の入力の方法 によっては, 単一の区画や板のみでなく複数の区画や板を 対象とすることも可能である。またTarget Room Object 又は Target Plate Object の生成と同時に設計情報である Reinforce Information Object が生成される。

（2）補強部材の存在を决定する設計情報の入力

内構部材設計機能を使用する際に, 補強部材の名前を入 力し, 補強部材の存在を决定する Reinforce Plate Object を生成する。尚, Reinforce Plate Object は Reinforce Information Object の情報として管理される。

（3）状態を決定する設計情報の入力

寸法情報を入力し How To Divide Object を生成する。 生成された寸法情報は, Reinforce Information Object の 情報として管理されることになる。 
（4）製品情報や関係情報の生成

設計情報を基に内構部材設計機能を使用し，設計情報の 適用対象となる全ての区画や板に，新たな補強部材を生成 する。ここで, 新たな補強部材は, 設計情報によって名前 の情報(Plate Name Object)を獲得するので, 名前の情報 を利用して縦の関係や横の関係を生成することが可能であ る。

\section{8. 記述された情報の利用}

システム上に様々な情報が記述されても, 記述された情 報を利用できなければ情報量が増えるだけで無意味であ る。設計者には，記述された情報がどのように利用できる かが重要である。そこで本章では記述された情報を利用し てどのようなことができるかについて述べる。

\section{1 設計変更への利用}

本研究では，製品情報や関係情報を生成するための設計 情報（仕切る・補強する）を明確にし, 計算機上に記述し てある。設計情報は設計者の意志決定の結果, 生成された と考えることができ, また, 設計変更は設計者の意志決定 が変更されたと考えることができる。このため, 本研究で は設計変更を設計情報の変更であると考えている。システ ム上に記述された設計情報が書き換えられた場合には，設 計情報や関係情報を利用してシステムが自動的に製品情報 や関係情報を獲得することが可能である。

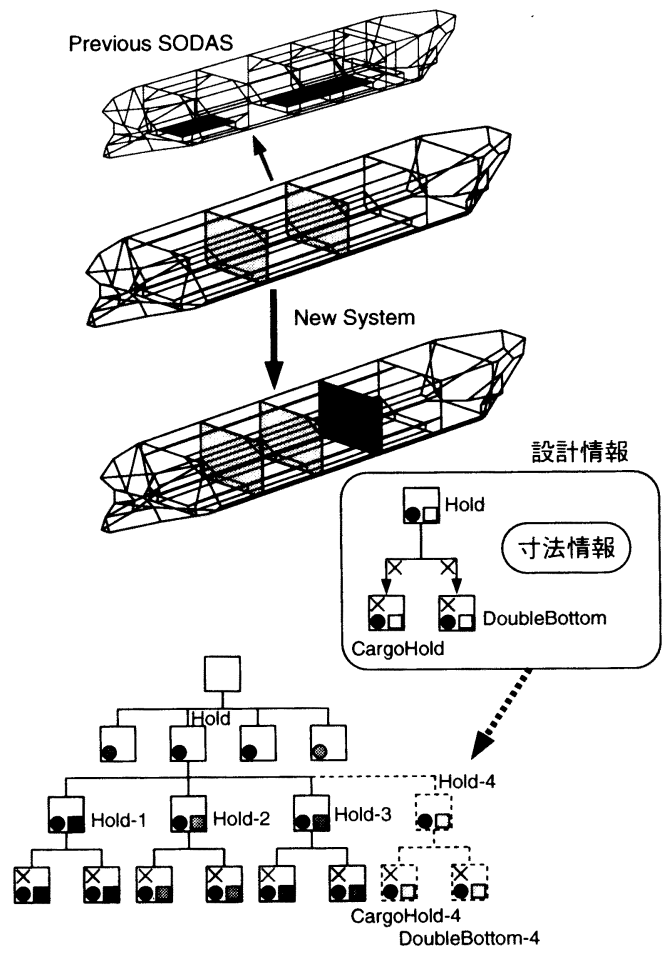

Fig. 14 Design Modification ( 1)
（1）設計変更への利用（その 1）

Fig. 14 は「Hold を NO. 1 から NO. 3 に仕切る」という 設計情報が「Hold No. 1 から NO. 4 に仕切る」という設 計情報に書き換えられた場合の例を示している。設計変更 前の船には以下に示す設計情報が記述されている。

a) Hull を Stem, Stern, Hold, EngineRoomに仕切 る。

b) Hold を No. 1 から NO. 3 に仕切る。

c） Hold を CargoHold 等に仕切る。(中央断面部を定 義)

この変更においては，新たに生成された Hold-NO. 4 に も Hold という名前が獲得されている。また,バルクキャリ アーの中央断面部の構造を定義する設計情報は, Hold と いう名前の情報を持つ全ての部屋に対して適用される。従 って, Hold-NO. 4 にもバルクキャリアーの中央断面部の 構造が定義される。

（2）設計変更への利用（その 2）

Fig. 15 は Inner Bottom Plate の高さを変更した例であ る。この船は次の設計情報を持つ。

a) Hull を Stem, Stern, Hold, EngineRoom に仕切 る。

b) Hold No. 1 から NO. 4 に仕切る。

c) Hold を Cargo Hold 等に仕切る。

d) Inner Bottom Plate をロンジで補強する。

この変更では，c）を構成する情報の 1 つである「Hold を Inner Bottom Plate によって Cargo Hold と Double Bottom に仕切る」という設計情報の中の寸法情報が書き換え られている。この設計情報は全ての Hold と関係している ので，一度に全ての二重底の高さを変更することが可能で ある。

8.2 他の船への利用

本システムでは，過去に設計された船において生成され

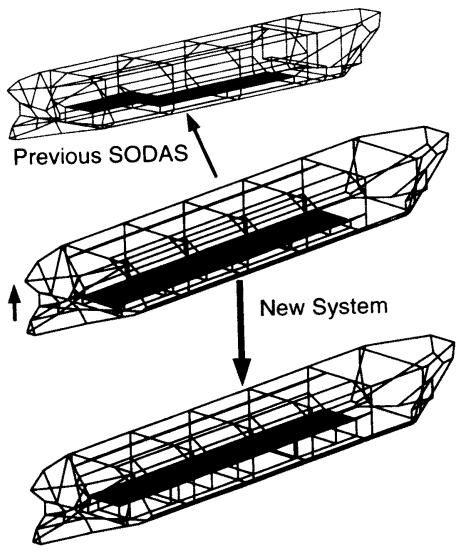

Fig. 15 Design Modification ( 2) 
た設計情報を，新たな船において利用することが可能であ る。Fig. 16 は異なる 4 隻からそれぞれの設計情報を移植 し，新しい船の設計を行ったものである。

移植された設計情報を以下に示す。

a) Hull \&tem, Stern, Front-Hold, Rear-Hold, Engine Room に住切る。

b) Front-Hold を No. 1 から NO. 4 に仕切る。

c) Hold を Cargo Hold 等に仕切る。

d) Bilge Tankを Floor-Plate で補強する。

e) Inner Bottom Plate をロンジで補強する。

尚, 設計情報を移植する順序は上記の通りに行う必要は なく，どのような順序でも構わない。

この利用例においては，まず，システムが各々の設計情 報の間の関係を調べることによって，各々の設計情報の間 に順序が自動的に作成される。例えば，a）とb)の間の順序 は次の様にして生成される。b)の適用対象は Front-Hold であるが, Front-Hold は a)の設計情報によって生成され る。以上の関係により，a）とb）の設計情報の間に手順が発 生する。

このように(て, a)と b)・a）と c)・c）とd）・c）と e)の 間に手順が生成され，その手順を統合することによって全

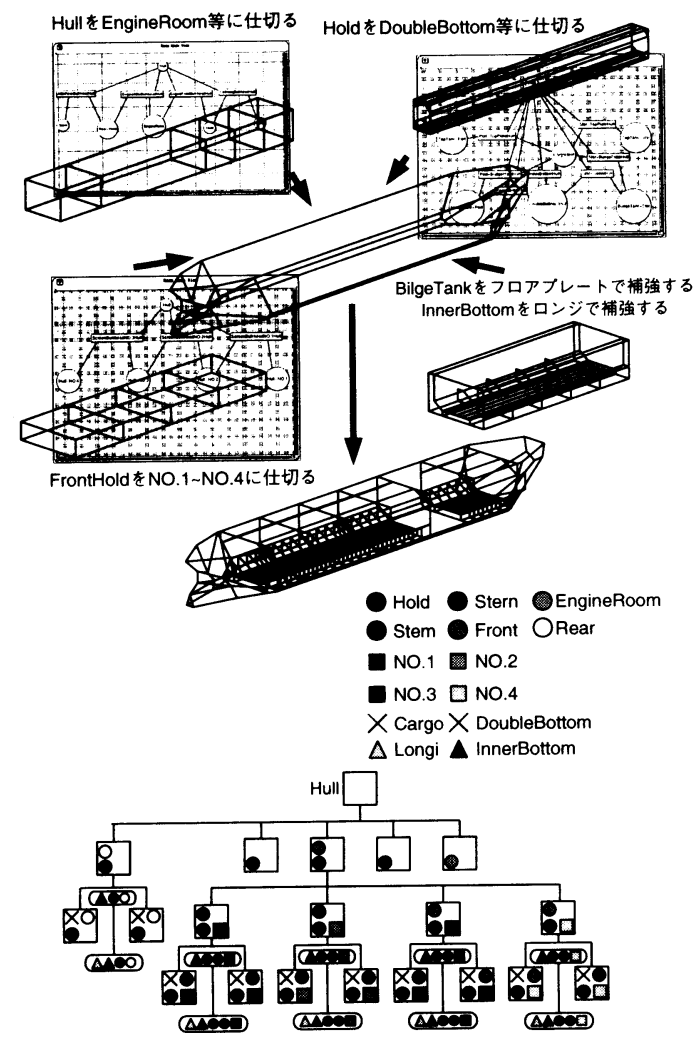

Fig. 16 Using Design Information in the Other Ship 体の手順が決定される。尚,b)と c)及びd）と e)の間には手 順はないが,このような場合は入力された順序に従って, 設計手順が決定される。

全体の設計手順が決定された後は，まず，一番目にある 設計情報を新たな船に適用し, 設計機能によって製品情報 が獲得される。そして,一番目の設計情報によって製品情 報が獲得されると, 次の設計情報を適用する。以上を繰り 返し全ての設計情報が適用された時点で終了する。

\section{9. 結}

言

本研究は関係情報に着目し，著者らの研究開発している SODAS 上に関係情報を記述し利用することを目的に行っ たものである。

本研究の結論を以下に示す。

（1）製品を表現するためには製品情報のみでは不足し ており，製品情報の間の階層関係（縦の関係）とネットワ ークの関係（横の関係）を記述する必要があることを明確 にした。

（2）関係情報や製品情報を効率良く生成するために区 画設計と内構部材の設計のモデル化を行った。そして, 区 画設計を「仕切る」という設計情報が繰り返し生成される 過程, 内構部材の設計を「補強する」という設計情報が繰 り返し生成される過程と捉えた。

（3）設計情報と関係情報の表現手法について検討し, 名前の概念 (属性情報) を用いて情報のモデル化を行った。

（4）情報のモデル化を基にプロトタイプ・システムを 構築することによって, 本研究によって記述可能になった 関係情報が有効に利用できることを示した。

最後に，本研究は科学研究費の援助を受けていることを 記し,ここに感謝致します。

\section{参 考 文 献}

1）吉川・冨山編：インテリジェント CAD（上・下）, 朝 倉書店, $(1989,1991)$

2）野本・青山・田畑：造船 CIM のための設計生産情報 獲得支援システムの構築, 日本造船学会論文集第 166 号, pp. 425-433, (1989)

3）野本・青山・早川・酒巻：船体の汎用設計支援シス テムの研究一造船 CIM のための設計生産情報獲得 支援システムの構築（その 4) 一, 日本造船学会論文 集第 170 号, pp. 779-789,（1991）

4）野本・青山・上原・児玉：製品定義システムにおけ る生産計画一造船 CIM のための設計生産情報獲得 支援システムの構築（その6)一, 日本造船学会論文 集第 172 号, pp. 693-702, (1992)

5）野本・青山・荒牧：構造記述法による船体構造設計 法に関する基礎的研究，日本造船学会論文集第 172 号, pp. 675-682, (1992)

6）池田勝：改訂船体各部名称図, 海文堂, (1979) 